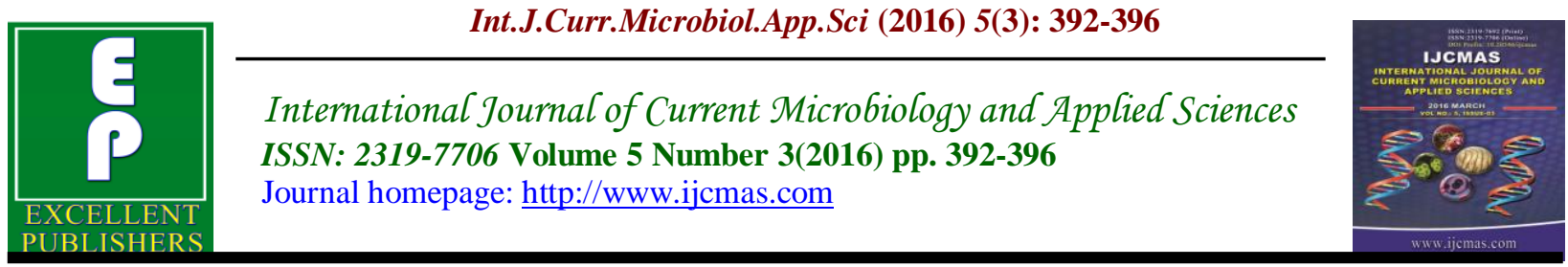

Case Study

http://dx.doi.org/10.20546/ijcmas.2016.503.046

\title{
Impact of Human Activities on Wetland: A Case Study from Bongaigaon District, Assam, India
}

\author{
Rahman Ahidur* \\ Department of Geography, Poona College of Arts, Science \& Commerce, Camp, Pune, India \\ *Corresponding author
}

\begin{abstract}
A B S T R A C T
Keywords

Wetland,

Human activity,

Tamaranga,

Bongaigaon

district, Assam

\section{Article Info}

Accepted:

18 February 2016

Available Online:

10, March 2016

The present investigation reveals that the impact of human activities on Tamaranga (beel) wetland a case study from Bongaigaon district, Assam, India. The wetland is situated $26^{\circ} 19^{\prime} 08^{\prime}$ ' $\mathrm{N}$ latitude and 90 $34^{\circ} 19^{\prime}$ ' $\mathrm{E}$ longitude in Bongaigaon district of Assam, covering an area of 627 ha. It is one of the inland of wetlands such as disturbances in physical, chemical and biological processes in an ecosystem and regulating climatic condition. The main human activities are use of wetland area for different natural wetland. The average annual rainfall is $3000 \mathrm{~mm}$. with maximum and minimum temperature of $36^{\circ} \mathrm{C}$ and $7^{\circ} \mathrm{C}$ respectively. The present study is focusing on the impact of human activities on functioning purposes like construction of houses, roads, agricultural land and overfishing etc. the area of wetland is going to decrease day by day due to human encroachment. It disturbing landscape functions cycling of carbon, water and nutrients, water purification, regulation of flow, support for animal migration etc. and increasing the risk of extreme events like, floods, droughts etc.
\end{abstract}

\section{Introduction}

Wetlands are one of the crucial natural resources. It is increasingly realized that the planet earth is facing grave environmental problems with fast depleting natural resources and threatening the very existence of most of the ecosystems. The wetlands are sometimes described as "the kidneys of the landscape" for their functions they perform in hydrological and chemical cycles and as downstream receivers of wastes from both natural and human sources (Mitch and Gosselink, 1986). At present Assam has an estimated area of 7, 64,372 ha under wetlands which is about 9.74 percent of the state's geographical area.
The majority (about 84\%) of these wetlands are formed by rivers and streams and riverine wetlands. Ramsar convention is the first modern global intergovernmental treaty on conservation and wise use of natural resources (www.ramsar.org). Ramsar convention entered into force in 1975. Under the text of the Convention (Article 1.1) wetlands are defined as: "areas of marsh, fen, peat-land or water, whether natural or artificial, permanent or temporary, with water that is static or flowing, fresh, brackish or salt, including areas of marine water the depth of which at low tide does not exceed six meters". In addition, the 
Convention (Article 2.1) provides that wetlands: "may incorporate riparian and coastal zones adjacent to the wetlands, and islands or bodies of marine water deeper than six meters at low tide lying within the wetlands".

Wetlands locally known as beels are the most common and integral features of the fluvial landscape of Assam. The wetlands are on the floodplains of the rivers Brahmaputra and Barak and their tributaries. There are large number of beels, swamps and marshes, locally known as jalah, doloni, hola and pitoni. All these water bodies comprise a vast sheet of water with varying shape, size and depth with rich flora and fauna.

\section{Materials and Methods}

The present study is the impact of human activities on the wetland as a case study from Bongaigaon district, Assam, India. The study is based on primary and secondary data collected from various sources such as Journals, Books, and other published work. The Tamaranga (beel) wetland is selected for the present study of physiography, biodiversity, use for human welfare in different role in functioning of ecosystem, landscape like cycling of carbon, water and nutrients, water purification, regulation of flow, support migration of birds, climate control, reducing extreme events like, flood, droughts etc.

\section{Results and Discussion}

Tamaranga-Dalani-Bhairab Complex includes the wetlands of Tamaranga, Konora, Paropota and Dalani, and an isolated hillock, Bhairab Pahar, in western Assam. This wetland is visited in all the seasons. It is observed that the wetland is encroached by different activities of human, such as construction of houses, roads, agricultural land and overfishing etc. In the winter season it is noted that due to decrease of water, the surrounding area is occupied by agricultural activities i.e. rabi crops. Due to increase in population the wetland area is occupied by agriculture and settlement. To develop transport system, road is also constructed in the wetland area. Being illiterate and underdeveloped area, the people are mainly engaged in primary activities i.e. fishing. Over fishing is also observed in the wetland area. The amount of fishing is decreasing due to practising fishing activities during the breeding season.

It is also investigated that in the agricultural field, around the wetland use of fertilizer and pesticide is harmful to the aquatic flora and fauna. As a result, biotic communities are depleting and polluting water.

This wetland is also supporting as a homeland of migratory birds. But it is observed that due to encroachment of the wetland, the number of migratory birds like Asian openbill stork is also decreasing.

Due to overfishing, especially in the breeding season, the quantity of fish will decrease very soon. Along with this, some species of fish will extinct like Botio dario, Colisa fasciatus etc. As a result it will be hampered economically to the people those who are engaged in fishing activities.

Encroachment of wetland will also be harmful in near future. If the encroachment will continue, then there will be disappear of wetland. It will create imbalance in the nature e.g. environment will be more polluted because wetlands are working just like a filter for the environment. Carbon dioxide gas will increase, as a result there will be depleting of ozone layer and it will create several diseases like skin cancer, 
bronchitis etc. to human being. The homelands of aquatic birds, plants and animals will be affected. All these are directly or indirectly need for human being. This will degrade the environment near future.

Use of chemical fertilizer and pesticide in the agricultural field around the wetland are also contributing water pollution and affecting the aquatic plants and animals.

In the present study it is investigated that human activities are using wetland area for different purposes like, construction of houses, roads, agricultural land and overfishing etc. the area of wetland is going to decrease day by day due to human encroachment. Similar studies are also studied by different researcher in different areas of the world which are mentioned below.

Jhingram (1993) opined that the wetlands are the world's most threatened habitats due to accelerated drainage, land reclamation, pollution and over-exploitation of wetland species. Classifying wetlands as wastelands should be avoided as wetlands play an important biological, cultural, economical, aesthetic and spiritual role (Asad Rahmani, BNHS Director). Global climate change is expected to become an important driver of loss and change in wet-land ecosystem (MEA, 2005; UNESCO, 2007). In a world of global climate change, wetlands are considered one of the biggest unknowns of the near future regarding element dynamics and matter fluxes (IPCC 2001; Paul et al.,. 2006). Though wetlands contribute about $40 \%$ of global methane $\left(\mathrm{CH}_{4}\right)$ emissions, they have the highest carbon (C) density among terrestrial ecosystems and relatively greater capacities to sequester additional carbon dioxide $\left(\mathrm{CO}_{2}\right)$ (Pant et al., 2003). Herpetologist Dr. Firoz Ahmed, who is familiar with a number of wetlands feel that a large number of wildlife, including amphibians will be seriously endangered with degradation of wetlands (The Assam Tribune, April18, 2012). Runoff from agricultural fields is the major source of non-point pollution for the Indian rivers flowing through Indo-Gangetic plains (Jain et al., 2007a,b). Eutrophication can reduce or eliminate fish populations (Verhoeven et $a l .$, 2006) Results from monitoring of Indian aquatic resources also show that water bodies, such as rivers and lakes, near to urban centres are becoming increasingly saprobic and eutrophicated due to the discharge of partly treated or untreated wastewater (Central Pollution Control Board, 2010). Water in most Asian rivers, lakes, streams and wetlands has been heavily degraded, mainly due to agricultural runoff of pesticides and fertilizers, and industrial and municipal wastewater discharges, all of which cause widespread eutrophication (Liu and Diamond, 2005; Prasad et al., 2002). Wetland plants provide breeding and nursery sites, resting areas for migratory species, and refuge from predators (Crance 1988). Pressures on wetlands are likely to be mediated through changes in hydrology, direct and indirect effects of changes in temperatures, as well as land use change (Ferrati et al., 2005).

The different researcher including the geographers have also conducted a number of studies on various aspects of the wetlands of the world e.g., Sarma and Goswami (1993), Deka et al. (1993), Bora and Barman (1998), Gopal (2000), Pfister (2001), Khandekar (2011), Bassi and Kumar (2012) and others has been highlighted.

In conclusion, from the above discussions it is crystal clear that wetland should be protected and states and local governments occupy perhaps the best position to take the 
lead on wetland protection because they are more aware of and responsive to local needs.

\section{Acknowledgement}

Author is very grateful to Dr. Kalim Shaikh, Assistant Professor, Poona College, Camp, Pune, for assisting in the observation and guidance of the research work.

\section{References}

Bassi, N., Kumar, M.D. 2012. Addressing the civic challenges: perspective on institutional change for sustainable urban watermanagement in India. Environ. Urban. Asia, 3(1): 165183.

Bora, A.K., Barman, B. 1998. A GeoEcological study of the wetlands of Barpeta District, Assam. North Eastern Geographer., 29(1-2): 4451.

Central Pollution Control Board (CPCB), 2010. Status of Water Quality in India 2009. Central Pollution Control Board, Ministry of Environment and Forests, Government of India, New Delhi.

Changnon, S.A., Huff, F.A., Hsu, C.F. 1988. Relations between precipitation and shallow ground water in Illinois. $J$. Clim1., 1239-1250.

Deka, C.R., Baruah, P., Goswami, D.C. 1993. Application of remote sensing in Wetland mapping- A case study from Deepor beel area near Guwahati. Proc. of Nat. Symp. on Remote Sensing Application for Resource Management with special emphasis on N.E. Region, Guwahati.

Gopal, Brij. 2000. Ramsar is not a strong, strict and rigid convention. Down to Earth, 9(1): 58.

Jain, C.K., Singhal, D.C., Sharma, M.K., 2007a. Estimating nutrient loadings using chemical mass balance approach. Environ. Monit. Assess., 134(1-3): 385-396.

Jhingram, V.G. 1993. Fish and Fisheries Ind., Hindusthan publishing corporation, New Delhi. pp. 195220, 415-419.

Juliano, K., Simonovic, S.P. 1999. The Impact of Wetlands on Flood Control in the Red River Valley. Natural Resource Institute, University of Manitoba, Manitoba, Canada.

Khandekar, N. 2011. Delhi water bodies go under, almost. Hindustan Times February.

Lalchandani, N. 2012. Green zones packed as avian guests flocked. The Times of India December, 4.

Liu, J.G., Diamond, J. 2005. China's environment in a globalizing world. Nature, 435: 1179-1186.

Millennium Ecosystem Assessment (MEA), 2005. Ecosystems and Human Wellbeing: Wetlands and Water Synthesis. World Resources Institute, Washington, DC.

Mitch, W.J., Gossolink, J.G. 1993. Wetlands second edition. Van Nostrand Reinhold, New York.

Mitsch, W.I., Gosselink, I.G. 1986. Wetlands. Van Nostrand Reinhold, New York.

Pant, H.K., Rechcigl, J.E., Adjei, M.B. 2003. Carbon sequestration in wetlands: Concept and estimation. Food Agric. Environ., 1(2): 308-313.

Prasad, S.N., Ramachandra, T.V., Ahalya, N., Sengupta, T., Kumar, A., Tiwari, A.K., Vijayan, V.S., Vijayan, L. 2002. Conservation of wetlands of India - a review. Trop. Ecol., 43(1): 173-186.

Sarma, P. 1993. Geoecological study of beels and swamps in Nagaon and Marigaon districts of Assam. 
Unpublished Ph.D. Thesis, Dept. of Geography, Gauhati Univ., Guwahati.

Sarma, P., Goswami, D.C. 1993. Geoenvironmental study of wetlands (beels) in the Nagaon and Morigaon districts of Assam using satellite data. Proc. of Nat. Symp. on Remote Sensing Applications for Resource Management with special emphasis on N.E. Region, Guwahati.

The Times of India, Pune. Friday, September19, 2014. p- 4.

United Nations Educational, Scientific and Cultural Organization (UNESCO), 2007. Case Studies on Climate
Change and World Heritage. UNESCO World Heritage Centre, France.

Verhoeven, J.T.A., Arheimer, B., Yin, C., Hefting, M.M. 2006. Regional and global concerns over wetlands and water quality. Trends Ecol. Evol., 21(2): 96-103.

Zedler, J.B., Kercher, S. 2005. Wetland resources: status, trends, ecosystem services, and restorability. Аnnu. Rev. Environ. Res., 30(1): 39-74.

Zektser, I.S., Loaiciga, H.A. 1993. Groundwater fluxes in the global hydrological cycle: past, present and future. J. Hydrol., 144: 405-427.

\section{How to cite this article:}

Rahman Ahidur. 2016. Impact of Human Activities on Wetland: A Case Study from Bongaigaon District, Assam, India. Int.J.Curr.Microbiol.App.Sci. 5(3): 392-396. doi: http://dx.doi.org/10.20546/ijcmas.2016.503.046 